\title{
The Relationship between Stature and Insolation: Evidence from Soldiers and Prisoners
}

\author{
Scott Alan Carson
}

CESIFO WORKING PAPER NO. 2850

CATEGORY 4: LABOUR MARKETS

NOVEMBER 2009

\footnotetext{
An electronic version of the paper may be downloaded

- from the SSRN website: www.SSRN.com

- from the RePEc website: www.RePEc.org - from the CESifo website: www.CESifo-group.org/wp
} 


\title{
The Relationship between Stature and Insolation: Evidence from Soldiers and Prisoners
}

\begin{abstract}
Nineteenth century white US statures varied with nutrition, disease exposure, and the physical environment. An additional explanation for stature growth is vitamin D production. Vitamin $\mathrm{D}$ is produced internally by the synthesis of cholesterol and sunlight in the epidermis. However, studies that link stature to insolation and vitamin D production rely on only one comprehensive data set. To test the relationship between insolation and stature further, this study broadens the sample to include both 19th century white Civil War recruits and prisoners, and illustrates that the relationship between stature and insolation was remarkably similar between white soldiers and prisoners, adding to the evidence that there is a positive relationship between stature and insolation.
\end{abstract}

JEL Code: I10.

Keywords: stature, insolation vitamin D.

Scott Alan Carson

University of Texas, Permian Basin

4901 East University

Odessa, TX 79762

USA

carson_s@utpb.edu

Please do not cite without permission from the author.

I appreciate comments from Paul Hodges, Larry Wimmer, and Tom Maloney. Owen WallaceServera, Sandy Triepke and Anita Voorhies provided excellent research assistance. All errors are my own. 
The Relationship between Stature and Insolation: Evidence from Soldiers and Prisoners

\section{Introduction}

The use of height data to measure living standards is now a well-established method in economics (Fogel, 1994, p. 138; Steckel, 1995; Steckel, 2009; Deaton, 2008; Case and Paxson, 2008). A populations' average stature reflects the cumulative interaction between nutrition, disease exposure, work, and the physical environment (Steckel, 1979, pp. 365-367; Tanner, 1962, pp. 1-27). By considering average versus individual stature, genetic differences are mitigated, leaving only economic and physical environment's relationship with stature. When diets, health, and physical environments improve, average stature increases and decreases when diets become less nutritious, disease environments deteriorate, or the physical environment places more stress on the body. Therefore, when traditional measures are unavailable, stature provides considerable insights into understanding historical processes.

Numerous studies consider $19^{\text {th }}$ century US white stature variation, and a few patterns are now clear. Among the first unexpected findings was that while wages increased throughout the $19^{\text {th }}$ century, white statures ironically declined (Table 1; Komos, 1987; Margo and Steckel, 1983; Costa, 1993). Other studies show that a broad set of explanatory variables were associated with $19^{\text {th }}$ century stature variation. Better nutrition corresponds with taller average statures (Komlos, 1987; Haines, Craig, and Weiss, 2003). Exposure to disease and physically rigorous work regimens are associated with shorter 
statures. Average stature was also related with other characteristics, such as socioeconomic conditions, business cycles, and other measures for economic performance (Voth and Leunig, 1996, 2000, and 2006; Oxley, 2003 and 2006; Steckel, 2009, p. 7; Woitek, 2003; Sunder and Woiteck, 2005; Strauss, 1995; Svedburg, 2000; Steckel, 1983; Cavelaars et al, 2000; Alter and Oris, 2008). Still other studies rely more heavily on biological explanations, specifically solar radiation, human biology, and vitamin D production, and a stature-insolation relationship suggests there is a positive relationship between stature and vitamin D production (Carson, 2008, 2009).

Nonetheless, these stature-insolation studies rely on a single population and are yet to be confirmed across independent samples. 
Table 1, Comparison of $19^{\text {th }}$ Century White Stature Studies

\begin{tabular}{|c|c|c|c|c|}
\hline Study & Birth Period & Sample & AStature & $\begin{array}{c}\text { Farmer Stature } \\
\text { Advantage }\end{array}$ \\
\hline $\begin{array}{c}\text { Sokoloff and } \\
\text { Vilaflour, } 1983\end{array}$ & $1720-1753$ & $\begin{array}{c}\text { Military, } \\
\text { French and } \\
\text { Indian War }\end{array}$ & $2.5 \mathrm{~cm}$ & .07 to $.88 \mathrm{~cm}$ \\
\hline $\begin{array}{c}\text { Margo and } \\
\text { Steckel, } 1983\end{array}$ & 1820-1840 & $\begin{array}{c}\text { Military, Civil } \\
\text { War, Adult }\end{array}$ & .483 & 1.21 \\
\hline $\begin{array}{c}\text { Komlos Cadets, } \\
1987\end{array}$ & 1820s-1870s & $\begin{array}{l}\text { Military, West } \\
\text { Point, Youth }\end{array}$ & .720 & $\mathrm{Na}$, but + \\
\hline $\begin{array}{c}\text { Steckel and } \\
\text { Haurin, } 1994\end{array}$ & $1845-1900$ & $\begin{array}{l}\text { Military, Ohio } \\
\text { National Guard }\end{array}$ & -1.27 & 1.40 \\
\hline $\begin{array}{l}\text { Komlos and } \\
\text { Coclanis, The } \\
\text { Citadel, } 1995\end{array}$ & 1830-1930 & $\begin{array}{c}\text { Military, The } \\
\text { Citadel }\end{array}$ & 6.60 & $\mathrm{Na}$ \\
\hline Sunder, 2004 & 1830-19060 & $\begin{array}{l}\text { Prisoners, } \\
\text { Tennessee }\end{array}$ & 1.27 & $\mathrm{Na}$ \\
\hline Carson, 2008 & $\begin{array}{c}\text { Youth1840- } \\
1900 \\
\text { Adult, } 1820- \\
1890\end{array}$ & $\begin{array}{l}\text { Prisoners, } \\
\text { Missouri }\end{array}$ & $\begin{array}{l}\text { Youth } .397 \\
\text { Adult } .657\end{array}$ & $\begin{array}{l}\text { Youth .285 } \\
\text { Adult .794 }\end{array}$ \\
\hline Carson, 2008 & $\begin{array}{c}\text { Youth 1810- } \\
1890 \\
\text { Adult } 1780- \\
1880\end{array}$ & $\begin{array}{l}\text { Prisoners, } \\
\text { Pennsylvania }\end{array}$ & $\begin{array}{l}\text { Youth } .880 \\
\text { Adult }-1.44\end{array}$ & $\begin{array}{l}\text { Youth } 1.92 \\
\text { Adult } 1.26\end{array}$ \\
\hline Carson, 2009 & 1800-1899 & $\begin{array}{l}\text { Prisoners, } \\
\text { United States }\end{array}$ & -1.63 & 1.21 \\
\hline Carson, 2009 & $\begin{array}{c}\text { Youth 1850- } \\
1900 \\
\text { Adult 1820- } \\
1895\end{array}$ & $\begin{array}{l}\text { Prisoners, } \\
\text { Texas }\end{array}$ & $\begin{array}{l}\text { Youth -.245 } \\
\text { Adult }-1.01\end{array}$ & $\begin{array}{l}\text { Youth } 1.88 \\
\text { Adult } 1.58\end{array}$ \\
\hline
\end{tabular}

Notes: Sokoloff and Vilaflour, 1983, Table, p. 462, time trend for native laborers and foreign artisans; Carson, 2009, US prisoners, p. 155; Carson, 2008, Missouri prisoners, pp.598-599; Carson, 2008, Pennsylvania prisoners, pp. 362-365; Steckel, 1994, pp. 160161; Steckel and Haurin, 1994, p. 124; Komlos, 1987, p. 901. Birth decade is stature averaged across ages in 1820 and 1870; Komlos and Coclanis, 1995, p. 100. The Citadel is stature by birth decade; Margo and Steckel, 1983, pp. 169-170, Table 1. Non-farm is weighted average of the intercepts. Sunder (2004). 
This study draws upon two large $19^{\text {th }}$ century stature data sets-white Civil War recruits and white state penitentiary inmates — to assess factors associated with white stature variation and to determine if the stature-insolation hypothesis is observed across two independently collected samples. Three paths of inquiry are considered. First, how did $19^{\text {th }}$ century white statures compare between two different socioeconomic groups? This paper demonstrates that the statures of soldiers and prisoners were similar throughout the $19^{\text {th }}$ century. Second, how did soldier and prisoner statures vary with insolation, the primary source of vitamin $\mathrm{D}$ ? The relationship between stature and insolation for Civil War soldiers and $19^{\text {th }}$ century prisoners were remarkably similar, and sensitivity analysis demonstrates that stature-insolation effects were similar between soldiers and prisoners. Third, for both soldiers and prisoners, what was the relationship between stature and occupation? The farmer stature advantage among soldiers was comparable to the farmer stature advantage among prisoners, indicating the relationships between stature, insolation, and socioeconomic status were similar across two independent $19^{\text {th }}$ century samples.

II. Data

Testing the stature-insolation hypothesis across independent samples requires three unique data sources. First, a reasonable measure for solar radiation is necessary. Second, two independently drawn stature samples are required. Military records represent biological living conditions among a higher socioeconomic segment of society, 
and prison records represent conditions among a lower socioeconomic status segment of society.

\section{United States' Insolation}

Calcium and vitamin D are two chemical elements required throughout life for healthy bone and teeth formation; however, their abundance are most critical during younger ages (Wardlaw, Hampl, and Divilestro, 2004, pp. 394-396; Tortolani et al, 2002, p. 60). Calcium generally comes from dairy products, and vitamin D in not dietary but is produced by the synthesis of cholesterol and sunlight in the epidermises' stratum granulosum (Holick, 2007 video; Holick, 2004a, pp. 363-364; Nesby-O’dell, 2002, p. 187; Loomis, 1967, p. 501; Norman, 1998, p. 1108; Holick, 2007). Greater direct sunlight (insolation) produces more vitamin D, and vitamin D is related to adult terminal statures (Xiong et al, 2005, pp. 228, 230-231; X-ZLiu et al, 2003; Ginsburg et al 1998; Uitterlinden et al, 2004). ${ }^{1}$ After the circulatory system contains sufficient amounts of vitamin D and to avoid vitamin D toxicity, vitamin D production is restricted within the stratum granulosum and residual vitamin D is broken down into inert matter (Holick et al, 1981, pp. 591-592; Jablonski, 2006, p. 62; Holick, 2001, p. 20; Holick, 2004a, p. 363). This self-limiting vitamin D effect may account for white stature variation with insolation, because at North American latitudes whites are close to the natural threshold where vitamin D production is curtailed (Jablonski, 2006, p. 62; Carson, 2009, pp. 150 and 154). At the opposite extreme, insufficient vitamin D has been linked to rickets,

\footnotetext{
${ }^{1}$ Carson (2009, pp. 150 and 154) demonstrates that $19^{\text {th }}$ statures were related to various factors, including the primary source of vitamin D production (insolation).
} 
osteomalasia, auto-immune diseases, and certain cancers (Holick, 2001, p. 28; Garland et al, 2006, pp. 252-256; Grant et al, 2003, p. 372).

To account for the relationship between vitamin $\mathrm{D}$ and stature, a measure is constructed that accounts for solar radiation. Insolation is the incoming direct sunlight that reaches the earth, its atmosphere, and surface objects. ${ }^{2}$ Insolation and ultraviolate B are also the primary source of vitamin D production (Holick, 1981, p. 590; Holick, 2007, p. 270). Because of its distance from the equator, European insolation is comparatively low, and before their migration to North America, Europeans at low insolation latitudes had to be more efficient in vitamin D production. As early hominids migrated out of Africa to Northern latitudes, they received less solar radiation, and through the process of natural selection, darker pigmented hominids were less successful hunter-gatherers in Northern latitudes and were selected-out (Loomis, 1967, pp. 503-504).

Because US historical insolation is unavailable, a modern insolation index (19932003) is constructed, and monthly insolation values are measured from January through June. The insolation index measures statewide average insolation levels across each of the states based on the hours of direct sunlight per day at county centroids in each state. ${ }^{3}$

\footnotetext{
${ }^{2}$ Insolation is an acronym for incident solar radiation, and is a measure for sunlight energy received for a given surface area at a given time. If w equals watts, m equals meters, and i equals insolation, $i=\frac{w}{m^{2}}=\frac{k w h}{m^{2} \cdot d a y}$. Data for US insolation is available from the National Aeronautics and Space Administration at http://eosweb.larc.nasa.gov/cgi-bin/sse/sse.cgi.

${ }^{3}$ Insolation is not the insolation in the county that surround's the state's centroid, but insolation in each county’s geographic center. The range of state insolation values extends from Maine’s minimum of 3.43 hours of direct sunlight to Arizona's maximum of 5.22 hours of direct sunlight per day.
} 
Each state estimate was then determined by summing the average hours of direct sunlight for each county (at its centroid), weighted by the proportion of the county's total land area (in square miles) to the state's total land area (in square miles). While this index is a rough approximation for historical insolation, it provides sufficient detail to capture state latitudinal insolation variation and consequently, vitamin D production. Predictably, Southern states have greater insolation than Northern states. For example, Texas receives 1.43, or 29 percent, more hours of direct sunlight per day than New York. It is also difficult to interpret insolation's net direct effect on human health, because greater insolation reduces calories required to maintain body temperature and produces more vitamin D, but greater insolation also warms surface temperatures, which may have made disease environments less healthy from water-borne diseases, especially in the South (Steckel, 1992, p. 501).

\section{Military Records}

All historical height data have various biases. Data used to study $19^{\text {th }}$ century white military statures is drawn from the Union Army Recruits in White Regiments books archived at the University of Chicago's Center for Population Economics. ${ }^{4}$ The White Regiment records were first gathered by collecting a sample of early $19^{\text {th }}$ century males mustered into the Union Army between 1861 and 1865. A list of over 20,000 companies was then extracted. A target sample of approximately 40,000 individuals was decided upon, and 331 companies were selected, producing an initial sample size of 39,616 soldiers. After eliminating immigrants and soldiers born before 1800 and after 1849 , there are 24,820 white native military recruits available from these white regiment

\footnotetext{
${ }^{4}$ Union Army Recruits in White Regiment data is accessed at http://www.cpe.uchicago.edu/data/data.html.
} 
records to compare the statures of a high socioeconomic status military cohort to those in a lower socioeconomic status prison cohort.

Table 2, Nineteenth Century US State Enlistment State and Penitentiaries

\begin{tabular}{l|cccc}
\hline & \multicolumn{3}{|c}{ White Recruits } & White Prisoners \\
\hline Prison & $\mathrm{N}$ & Percent & $\mathrm{N}$ & Percent \\
Alabama & 23 & .09 & 218 & .72 \\
Arkansas & 23 & .09 & 97 & .32 \\
Connecticut & 421 & 1.70 & 212 & .70 \\
Deleware & 301 & 1.21 & 76 & .25 \\
Wasington DC & 21 & .08 & 62 & .21 \\
Georgia & 25 & 10 & 280 & .93 \\
Illinois & 1,289 & 5.19 & 1,431 & 4.73 \\
Indiana & 1,505 & 6.06 & 942 & 3.12 \\
Iowa & 118 & .48 & 173 & .57 \\
Kansas & 15 & .06 & 34 & .11 \\
Kentucky & 1,015 & 4.09 & 2,749 & 9.09 \\
Louisiana & 25 & .10 & 357 & 1.18 \\
Massachusetts & 620 & 2.50 & 689 & 2.28 \\
Maryland & 439 & 1.77 & 703 & 2.33 \\
Maine & 478 & 1.93 & 209 & .69 \\
Michigan & 510 & 2.05 & 245 & .81 \\
Minnesota & 1 & .00 & 13 & .04 \\
Mississippi & 16 & .07 & 176 & .58 \\
Missouri & 418 & 1.68 & 1,416 & 4.68 \\
Nebraska & 2 & .01 & 4 & .01 \\
New Hampshire & 445 & 1.79 & 109 & .36 \\
New Jersey & 584 & 2.35 & 463 & 1.53 \\
New Mexico & 68 & .27 & 38 & .13 \\
New York & 5,134 & 20.68 & 4,727 & 15.63 \\
North Carolina & 113 & .46 & 269 & .89 \\
Ohio & 5.491 & 22.12 & 4,954 & 16.39 \\
Pennsylvania & 3,832 & 15.44 & 6,247 & 20.66 \\
Rhode Island & 44 & .18 & 92 & .30 \\
South Carolina & 24 & .10 & 166 & .55 \\
Tennessee & 321 & 1.29 & 1,015 & .36 \\
Texas & 3 & .01 & 251 & .83 \\
Vermont & 624 & .251 & 298 & .99 \\
Virginia & 529 & 2.13 & 1,306 & 4.32 \\
Wisconsin & 175 & .71 & 119 & .39 \\
West Virginia & 168 & .68 & 94 & .31 \\
\hline Total & 24,820 & 100.00 & 30,234 & 100.00 \\
\hline & & & &
\end{tabular}


Source: Data used to study white anthropometrics is a subset of a much larger $19^{\text {th }}$ century prison sample. All available records from American state repositories have been acquired and entered into a master file. These records include Arizona, California, Colorado, Idaho, Illinois, Kansas, Kentucky, Missouri, New Mexico, Ohio, Oregon, Pennsylvania, Texas, Utah and Washington.

Notes: Stature is in centimeters. The occupation classification scheme is consistent with Ferrie (1997). 
Regiment enumerators recorded soldier characteristics at the time of enlistment, and only soldiers identified as whites by military enlistment officers are included in the White Regiment books. Physical descriptions in the White Regiment books were recorded at the time of enlistment with great care as a means of identification because accurate measurements had identification implications in the event of death or desertion; accurate physical descriptions were also used to limit bounty jumping, where recruits enlisted to collect financial enlistment rewards, only to desert and collect additional enlistment bonuses at other recruiting stations. Military enumerators routinely recorded conscription dates, age, nativity, and stature; therefore, enlistment characteristics reflect pre-incarceration conditions. Regiment enumerators also recorded pre-military occupations, and these occupations are classified into four categories: merchants and high skilled workers are classified as white-collar workers; light manufacturers, craft workers, and carpenters are classified skilled workers; agricultural workers are classified as farmers; laborers and miners are classified as unskilled workers. Most recruits were from middle-Atlantic states, such as Ohio, New York, and Pennsylvania (Table 2). The soldier sample is also probably rural because most white soldiers in the sample were farmers. ${ }^{5}$

\section{United States' Prison Data}

To contrast the stature-insolation relationship of a high socioeconomic group with low socioeconomic group, a data set from a lower socioeconomic group is required. Prisoners, that segment of society most vulnerable to economic change, may have selected a number of the materially poorest individuals, although there were skilled prisoners in the sample (Bogin, 1991, p. 288; Komlos and Baten, 2004, p. 199; Nicholas

${ }^{5}$ Costa, 1993, p. 359. 
and Steckel, p. 944). Moreover, if at the margins of subsistence, demographic, socioeconomic factors, and insolation were more significant in stature attainment, prison records may illustrate these effects more clearly. Most whites in the prison sample were imprisoned in Ohio, Missouri, Texas, and Pennsylvania prisons (Table 2).

There also is concern over prison entry requirements, and physical descriptions were recorded by prison enumerators at the time of incarceration as a means of identification, therefore, reflect pre-incarceration conditions. Between 1830 and 1920, prison officials routinely recorded the dates inmates were received, age, complexion, nativity, stature, pre-incarceration occupation, and crime. All prison records with complete age, stature, occupation, and nativity were collected. There was care recording inmate statures because accurate measurement had legal implications for identification in the event that inmates escaped and were later recaptured. ${ }^{6}$ Arrests and prosecutions across states may have resulted in various selection biases that may affect the results of this analysis. However, white stature variations within US prisons are consistent with other stature studies (Steckel, 1979; Margo and Steckel, 1982; Nicholas and Steckel, 1991, pp. 941-943; Komlos, 1992; Komlos and Coclanis, 1997; Bodenhorn, 1999; Sünder, 2004).

Fortunately, inmate enumerators were quite thorough when recording inmate complexion and occupation. For example, enumerators recorded inmates' race in a complexion category, and enumerators recorded white complexions as light, medium, dark, and fair. The white inmate complexion classification is further supported by European immigrant complexions, which were always of fair complexion and were also

\footnotetext{
${ }^{6}$ Many inmate statures were recorded at quarter, eighth, and even sixteenth increments.
} 
recorded as light, medium, and dark. ${ }^{7}$ Inmate enumerators recorded a broad continuum of occupations and defined them narrowly, recording over 200 different occupations, which are classified here into four categories: merchants and high skilled workers are classified as white-collar workers; light manufacturing, craft workers, and carpenters are classified as skilled workers; workers in the agricultural sector are classified as farmers; laborers and miners are classified as unskilled workers (Tanner, 1977, p. 346; Ladurie, 1979; Margo and Steckel, 1992; p. 520). Unfortunately, inmate enumerators did not distinguish between farm and common laborers. Since common laborers probably encountered less favorable biological conditions during childhood and adolescence, this potentially overestimates the biological benefits of being a common laborer and underestimates the advantages of being a farm laborer. To make meaningful comparisons across the soldier and prisoner samples, only white males are included in this analysis, and age, nativity, and birth-cohort characteristics are restricted in each sample to only males born between 1800 and 1849 in the same states and between the ages of 15 and 59.

\section{Soldier and Prisoner Summary Statistics}

Because the height distribution is itself a function of the age distribution, a height index is constructed for both soldier and prisoner samples to determine if statures were distributed symmetrically and whether there were arbitrary truncation points imposed on soldier and prisoner statures, either by military recruitment standards, law enforcement,

\footnotetext{
${ }^{7}$ I am currently collecting $19^{\text {th }}$ century Irish prison records. Irish prison enumerators also used light, medium, dark, fresh and sallow to describe white prisoners in Irish prisons from a traditionally white population. To date, no inmate in an Irish prison has been recorded with a complexion consistent with African heritage.
} 
or state legislation. This index is calculated by first calculating the average stature for each age group; each observation is then divided by the average stature for the relevant age group (Komlos, 1987, p. 899). Figure 1 demonstrates that white soldier and prisoner statures were distributed approximately symmetric and there is little evidence of stature heaping or arbitrary truncation points.

Figure 1, National Black and White Stature Histograms by Age Group
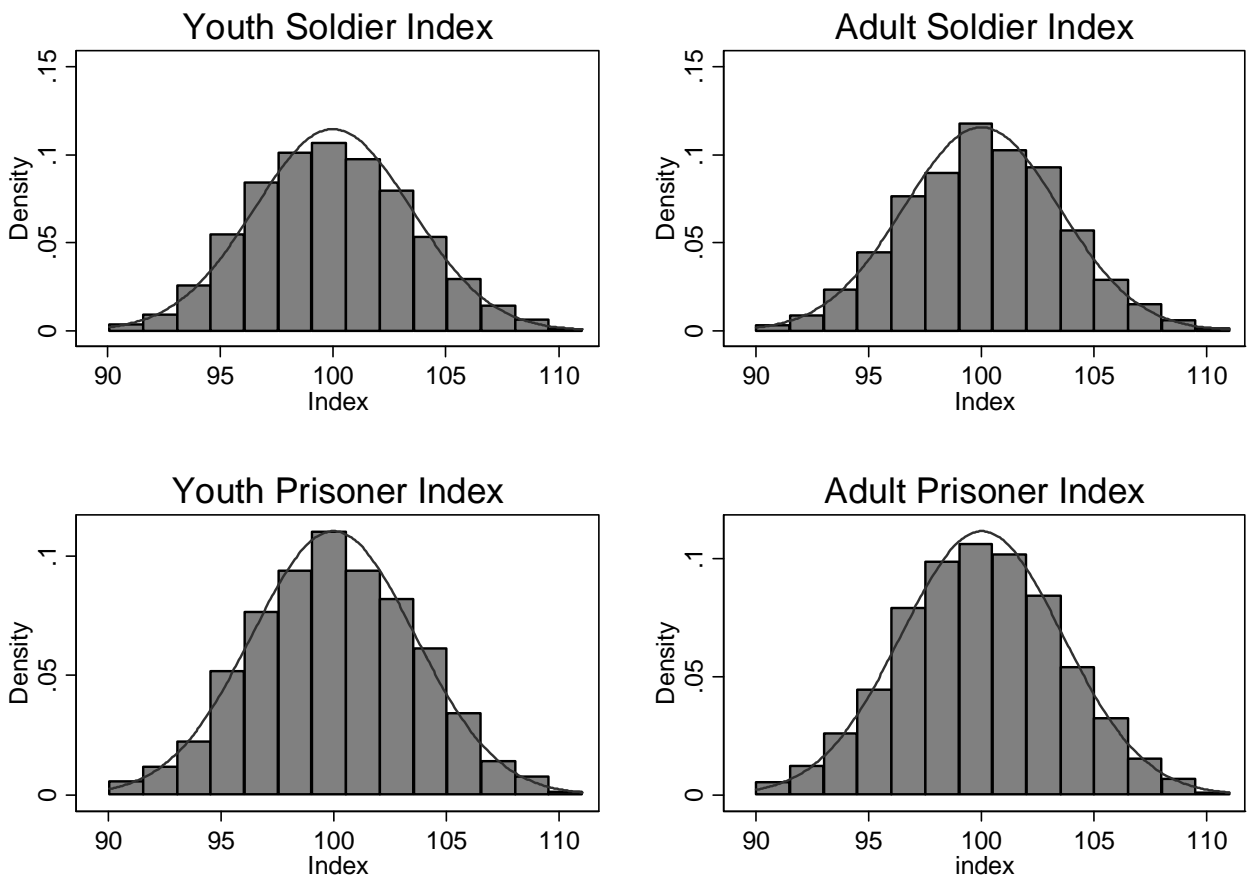

Source: see Table 2 . 
Table 3, National Military and Prison Data White Descriptive Statistics

\begin{tabular}{l|ccccccccc}
\hline & $\begin{array}{c}\text { White } \\
\text { Recruits }\end{array}$ & \multicolumn{7}{c}{$\begin{array}{c}\text { White } \\
\text { Prisoners }\end{array}$} \\
\hline Ages & $\mathrm{N}$ & Percent & Mean & S.D. & $\mathrm{N}$ & Percent & Mean & S.D. & \\
Teens & 6,993 & 28.15 & 169.80 & 6.52 & 1,917 & 6.34 & 169.34 & 6.49 & .46 \\
20s & 12,239 & 49.26 & 173.37 & 6.27 & 12,883 & 42.61 & 171.73 & 6.50 & 1.64 \\
30s & 3,962 & 15.95 & 174.11 & 6.37 & 7,896 & 26.12 & 172.39 & 6.49 & 1.72 \\
40s & 1,560 & 6.28 & 173.56 & 6.34 & 4,797 & 15.87 & 172.29 & 6.69 & 1.27 \\
50s & 91 & .37 & 175.80 & 6.03 & 2,741 & 9.07 & 171.96 & 6.55 & 3.84 \\
Birth & & & & & & & & & \\
Decade & & & & & & & & & \\
1800s & 51 & .21 & 176.23 & 5.60 & 783 & 2.59 & 172.40 & 6.47 & 3.83 \\
1810s & 662 & 2.66 & 173.72 & 6.51 & 2,248 & 7.44 & 172.61 & 6.62 & 1.11 \\
1820s & 3,022 & 12.16 & 173.90 & 6.42 & 3,843 & 12.71 & 172.48 & 6.81 & 1.42 \\
1830s & 7,931 & 31.92 & 173.93 & 6.29 & 7,496 & 24.79 & 171.93 & 6.60 & 2 \\
& & & & & & & & & \\
1840s & 13,179 & 53.04 & 171.25 & 6.54 & 15,864 & 52.47 & 171.55 & 6.48 & -.3 \\
Occupation & & & & & & & & & \\
White- & 365 & 1.51 & 172.29 & 6.73 & 3,086 & 10.21 & 171.43 & 6.35 & .86 \\
Collar & & & & & & & & & \\
Skilled & 4,466 & 18.44 & 172.20 & 6.40 & 8,852 & 29.28 & 171.40 & 6.41 & .80 \\
Farmer & 14,119 & 58.29 & 173.06 & 6.60 & 4,678 & 15.47 & 173.37 & 6.44 & -.31 \\
Unskilled & 5,274 & 21.77 & 171.34 & 6.48 & 13,618 & 45.04 & 171.74 & 6.70 & -.40 \\
Nativity & & & & & & & & & \\
North East & 2,632 & 10.59 & 172.45 & 6.29 & 1,609 & 5.32 & 171.15 & 6.54 & 1.3 \\
Middle & 10,323 & 41.55 & 171.74 & 6.45 & 12,307 & 40.71 & 170.60 & 6.35 & 1.14 \\
Atlantic & & & & & & & & & \\
Great & 8,980 & 36.14 & 173.07 & 6.57 & 7,662 & 25.34 & 172.65 & 6.41 & .42 \\
Lakes & & & & & & & & & \\
Plains & 555 & 2.23 & 172.80 & 7.19 & 1,640 & 6.42 & 172.05 & 6.59 & .75 \\
Southeast & 2,284 & 9.19 & 173.91 & 6.86 & 6,727 & 22.25 & 173.30 & 6.47 & .61 \\
Southwest & 71 & .29 & 166.04 & 7.71 & 289 & .96 & 166.60 & 6.17 & -.56 \\
\hline & & & & & & & & & \\
\hline
\end{tabular}

Source: See Table 2.

Notes: Stature is in centimeters. Youth age is between ages 15 and 22. The occupation classification scheme is consistent with Ferrie (1997); The following geographic classification scheme is consistent with Carlino and Sill (2000): New England= CT, ME, MA, NH, RI and VT; Middle Atlantic= DE, DC, MD, NJ, NY, and PA; Great Lakes= IL, IN, MI, OH, and WI; Plains= IA, KS, MN, MO, NE, ND, and SD; South East= AL, 
AR, FL, GA, KY, LA, MS, NC, SC, TN, VA, and WV; South West= AZ, NM, OK, and TX; Far West= CA, CO, ID, MT, NV, OR, UT, WA, and WY.

Table 3 presents white soldier and prisoner ages, birth decade, occupations, and nativity percentages. Although average statures are included, they are not reliable because of possible compositional effects, which are accounted for in the regression models that follow. Age percentages demonstrate that soldiers were enumerated at younger ages, prisoners at older ages. Consistent with older prisoner ages, prisoner birth years were earlier in the $19^{\text {th }}$ century than soldier birth years. Occupation distributions illustrate the counterintuitive result that inmates were consistently more skilled than soldiers. Much of this may be attributable to age profiles; prisoners were older than soldiers, were further along in their occupational life cycle, therefore, more likely skilled than soldiers. Soldier average age was 24.96; prisoner average wage was 32.30. Farmers in the soldier sample were overrepresented compared to farmers in the census (McPherson, 1988, pp. 607-608); unskilled workers in the prison sample were overrepresented compared to unskilled workers in the census (Rosenbloom, 2000, p. 88). Soldiers were also more likely to be from the Northeast and Great Lakes, while prisoners were more likely to be from the Plains and Southern states. Therefore, soldiers were more likely than prisoners to be young farmers from the Northeast and Great Lakes, while prisoners were more likely to be skilled from Plains and Southern states. ${ }^{8}$

\footnotetext{
${ }^{8}$ Because prison enumerators failed to distinguish between common and farm laborers, many unskilled prisoners were also farmers.
} 
III. Comparative Effects of Demographics, Socioeconomic Status on White Characteristics

Nineteenth century soldiers and prisoner statures were related to age, birth years, occupations, migration, and nativity. They may have also been related to insolation, which is the primary source of vitamin D production (Holick, 2007 video). We test which of these variables were associated with stature, and separate regressions are run on the military and prison samples. To start, soldiers and prisoners are partitioned into separate groups, and the $\mathrm{i}^{\text {th }}$ soldier and prisoner statures are assumed to be related with age, birth period, occupation, migration, nativity, and insolation.

$$
\begin{aligned}
& \text { Centimeter }_{i}=\alpha+\sum_{a=15}^{50} \beta_{a} \text { Age }_{i, a}+\sum_{t=1800}^{1839} \beta_{t} \text { Birth }_{i, t}+\sum_{l=1}^{4} \beta_{l} \text { Occupation }_{i, l}+\sum_{n=1}^{6} \beta_{n} \text { Nativity }_{i, n} \\
& +\beta_{\text {Mig }} \text { Migration }_{i, \text { Mig }}+\beta_{\text {Isol }} \text { Insol }_{i, \text { Insol }}+\beta_{\text {Insol }} \text { Insol }_{i, \text { Insol }}^{2}+\varepsilon_{i}
\end{aligned}
$$

Dummy variables are included for youth ages 15 through 22; adult age dummies are included for 40 and 50 year old age intervals. Birth decade dummies are in ten year intervals from 1800 through 1849. Dummy variables are included for white-collar, skilled, and agricultural occupations. Nativity dummy variables are included for birth in Northeast, Middle-Atlantic, Plains, Southeast, and Southwest regions. Lastly, continuous insolation and insolation squared terms are included to account for insolation and vitamin D production.

Tables 4 and 5's Model 1 includes unrestricted age, birth, occupations, nativity variables, and continuous insolation variables. This unrestricted model is then compared in Models 2 through 5 to restricted models for insolation, socioeconomic status, birth periods, and nativity. 
Table 4, Nineteenth Century White Prisoner Statures related to Birth Decade,

Occupations, Nativity, and Insolation.

\begin{tabular}{|c|c|c|c|c|c|}
\hline Coefficient & Unrestricted & $\begin{array}{c}\text { Insolation } \\
\text { Omitted }\end{array}$ & $\begin{array}{c}\text { SES } \\
\text { Omitted }\end{array}$ & $\begin{array}{l}\text { Birth-Period } \\
\text { Omitted }\end{array}$ & $\begin{array}{l}\text { Nativity } \\
\text { Omitted }\end{array}$ \\
\hline Intercept & $135.11^{* * *}$ & $172.14 * * *$ & $133.03 * * *$ & $132.23 * * *$ & $102.18 * * *$ \\
\hline \multicolumn{6}{|l|}{ Ages } \\
\hline 15 & $-8.77 * * *$ & $-8.80 * * *$ & $-8.73 * * *$ & $-8.71 * * *$ & $-8.48 * * *$ \\
\hline 16 & $-6.19 * * *$ & $-6.20 * * *$ & $-6.19 * * *$ & $-6.21 * * *$ & $-6.05 * * *$ \\
\hline 17 & $-3.19 * * *$ & $-3.19 * * *$ & $-3.14 * * *$ & $-3.25 * * *$ & $-3.06 * * *$ \\
\hline 18 & $-2.68 * * *$ & $-2.67 * * *$ & $2.64 * * *$ & $-2.73 * * *$ & $-2.62 * * *$ \\
\hline 19 & $-1.34 * * *$ & $-1.34 * * *$ & $-1.26 * * *$ & $-1.38 * * *$ & $-1.33^{* * *}$ \\
\hline 20 & $-1.14 * * *$ & -1.14 & $-1.07 * * *$ & $-1.15 * * *$ & $-1.12 * * *$ \\
\hline 21 & $-.478 * * *$ & $-.472 * * *$ & $-.417 * *$ & $-.502 * * *$ & $-.490 * * *$ \\
\hline 22 & -.263 & -.253 & -.235 & $-.295^{*}$ & -.267 \\
\hline $23-29$ & Reference & Reference & Reference & Reference & Reference \\
\hline $30 s$ & $.374 * * *$ & $.370 * * *$ & $.353 * * *$ & $.432 * * *$ & $.415^{* * *}$ \\
\hline $40 \mathrm{~s}$ & .184 & .171 & .203 & $.324 * * *$ & $.218^{*}$ \\
\hline $50 \mathrm{~s}$ & $-.277 * *$ & $-.292 * *$ & $1.231^{*}$ & -.084 & $-.239 *$ \\
\hline \multicolumn{6}{|l|}{ Birth Decade } \\
\hline 1800 & $.993 * * *$ & $1.06 * * *$ & $1.08 * * *$ & & $.773 * * *$ \\
\hline 1810 & $1.26 * * *$ & $1.30 * * *$ & $1.29 * * *$ & & $1.19 * * *$ \\
\hline 1820 & $.938 * * *$ & $.970 * * *$ & $.967 * * *$ & & $.960 * * *$ \\
\hline 1830 & $.318^{* * *}$ & $.338 * * *$ & $.324 * * *$ & & $.360 * * *$ \\
\hline 1840 & Reference & Reference & Reference & Reference & Reference \\
\hline \multicolumn{6}{|l|}{ Occupations } \\
\hline White Collar & -.135 & -.158 & & -.200 & -.182 \\
\hline Skilled & $-.249 * * *$ & $-.254 * * *$ & & $-.218 * *$ & $-.277 * * *$ \\
\hline Farmer & $1.27 * * *$ & $1.27 * * *$ & & $1.31^{* * *}$ & $1.45^{* * *}$ \\
\hline Unskilled & Reference & Reference & Reference & Reference & Reference \\
\hline \multicolumn{6}{|l|}{ Nativity } \\
\hline Northeast & $-.160 * * *$ & $-1.72 * * *$ & $-1.82 * * *$ & $-1.46 * * *$ & \\
\hline Middle & $-1.92 * * *$ & $-2.09 * * *$ & $-2.13 * * *$ & $-1.80 * * *$ & \\
\hline \multicolumn{6}{|l|}{ Atlantic } \\
\hline Great Lakes & Reference & Reference & Reference & Reference & Reference \\
\hline Plains & $-.429 * *$ & $-.646 * * *$ & $-.529 * * *$ & $-.481 * * *$ & \\
\hline Southeast & $.709 * * *$ & $.463 * * *$ & $.577 * * *$ & $.868 * * *$ & \\
\hline Southwest & $3.87 * * *$ & $.803^{*}$ & $3.88 * * *$ & $4.10^{* * *}$ & \\
\hline \multicolumn{6}{|l|}{ Migration } \\
\hline Migrant & $.472 * * *$ & $.409 * * *$ & $.497 * * *$ & $.448 * * *$ & $.172 * *$ \\
\hline Non-Migrant & Reference & Reference & Reference & Reference & Reference \\
\hline \multicolumn{6}{|l|}{ Insolation } \\
\hline Insolation & $19.45 * * *$ & & $20.58 * * *$ & $21.18 * * *$ & $33.10 * * *$ \\
\hline Insolation $^{2}$ & $-2.55 * * *$ & & $-2.69 * * *$ & $-2.79 * * *$ & $-3.88 * * *$ \\
\hline
\end{tabular}




\begin{tabular}{l|ccccc}
\hline $\mathrm{N}$ & 30,234 & 30,234 & 30,234 & 30,234 & 30,234 \\
$\mathrm{R}^{2}$ & .0592 & .0582 & .0535 & .0554 & .0483 \\
\hline
\end{tabular}

Source: See Table 2. 
Table 5, Nineteenth Century White Soldier Statures related to Birth Decade, Occupations,

Nativity, and Insolation.

\begin{tabular}{|c|c|c|c|c|c|}
\hline & Unrestricted & $\begin{array}{c}\text { Insolation } \\
\text { Omitted }\end{array}$ & $\begin{array}{c}\text { SES } \\
\text { Omitted } \\
\end{array}$ & $\begin{array}{l}\text { Birth-Period } \\
\text { Omitted }\end{array}$ & $\begin{array}{l}\text { Nativity } \\
\text { Omitted } \\
\end{array}$ \\
\hline Coefficient & & & & & \\
\hline Intercept & $68.90 * * *$ & $171.67 * * *$ & $52.39 * * *$ & $69.03 * * *$ & $90.32 * * *$ \\
\hline \multicolumn{6}{|l|}{ Ages } \\
\hline 15 & $-15.76 * * *$ & $-15.18 * * *$ & $-15.09 * * *$ & $-16.24 * * *$ & $-15.25 * * *$ \\
\hline 16 & $-7.76 * * *$ & $-7.77 * * *$ & $-7.68 * * *$ & $-8.75 * * *$ & $-7.73 * * *$ \\
\hline 17 & $-4.98 * * *$ & $-4.94 * * *$ & $-4.87 * * *$ & $-5.97 * * *$ & $-4.97 * * *$ \\
\hline 18 & $-3.53 * * *$ & $3.51 * * *$ & $-3.30 * * *$ & $-4.53 * * *$ & $-3.53 * * *$ \\
\hline 19 & $-1.41^{* * *}$ & $-1.39 * * *$ & $-1.25 * * *$ & $-2.40 * * *$ & $-1.41^{* * *}$ \\
\hline 20 & .059 & .085 & .196 & $-.934 * * *$ & .060 \\
\hline 21 & .274 & .288 & $.373^{*}$ & $-.719 * * *$ & .271 \\
\hline 22 & $.336^{*}$ & $.333^{*}$ & $.413 * *$ & $-.31^{* *}$ & $.336 *$ \\
\hline $23-29$ & Reference & Reference & Reference & Reference & Reference \\
\hline $30 \mathrm{~s}$ & $.315^{*}$ & $.314^{*}$ & $.301 *$ & $.482 * * *$ & $.337 * *$ \\
\hline $40 \mathrm{~s}$ & -.216 & -.251 & -.216 & -.037 & -.168 \\
\hline $50 s$ & 1.14 & 1.10 & 1.39 & $1.89 * * *$ & 1.13 \\
\hline \multicolumn{6}{|l|}{ Birth Decade } \\
\hline 1800 & 2.16 & $2.29 *$ & 1.85 & & $2.26 *$ \\
\hline 1810 & $1.22 * * *$ & $1.21 * * *$ & $1.21 * * *$ & & $1.26 * * *$ \\
\hline 1820 & $1.15^{* * *}$ & $1.12 * * *$ & $1.16^{* * *}$ & & $1.16^{* * *}$ \\
\hline 1830 & $1.18 * * *$ & $1.18 * * *$ & $1.23 * * *$ & & $1.18 * * *$ \\
\hline 1840 & Reference & Reference & Reference & Reference & Reference \\
\hline \multicolumn{6}{|l|}{ Occupations } \\
\hline White Collar & .136 & .157 & & .152 & .099 \\
\hline Skilled & .115 & .156 & & .130 & .082 \\
\hline Farmer & $1.50 * * *$ & $1.63 * * *$ & & $1.52 * * *$ & $1.50 * * *$ \\
\hline Unskilled & Reference & Reference & Reference & Reference & Reference \\
\hline \multicolumn{6}{|l|}{ Nativity } \\
\hline Northeast & .018 & -.167 & -.072 & .059 & \\
\hline Middle & $1.56^{* * *}$ & $1.11 * * *$ & $1.61^{* * *}$ & $1.49 * * *$ & \\
\hline \multicolumn{6}{|l|}{ Atlantic } \\
\hline Great Lakes & Reference & Reference & Reference & Reference & Reference \\
\hline Plains & $1.03^{* * *}$ & $.844 * * *$ & $1.18 * * *$ & $1.04 * * *$ & \\
\hline Southeast & $.187 * * *$ & $.968 * * *$ & $.937 * * *$ & $.838 * * *$ & \\
\hline Southwest & $4.03 * *$ & $-6.27 * * *$ & $4.35^{* *}$ & $4.13^{* *}$ & \\
\hline \multicolumn{6}{|l|}{ Migration } \\
\hline Migrant & .075 & .015 & .135 & .079 & .079 \\
\hline Non-Migrant & Reference & Reference & Reference & Reference & Reference \\
\hline \multicolumn{6}{|l|}{ Insolation } \\
\hline Insolation & $53.90 * * *$ & & $62.62 * * *$ & $54.38 * * *$ & $41.77 * * *$ \\
\hline Insolation $^{2}$ & $-7.03 * * *$ & & $-8.12 * * *$ & $-7.10 * * *$ & $-5.31 * * *$ \\
\hline
\end{tabular}




\begin{tabular}{l|ccccc}
\hline $\mathrm{N}$ & 24,820 & 24,820 & 24,820 & 24,820 & 24,820 \\
$\mathrm{R}^{2}$ & .1076 & .1040 & .0964 & .1061 & .1060 \\
\hline
\end{tabular}

Source: See Table 2.

Figure 2, Soldier and Prisoner Youth Statures by Age

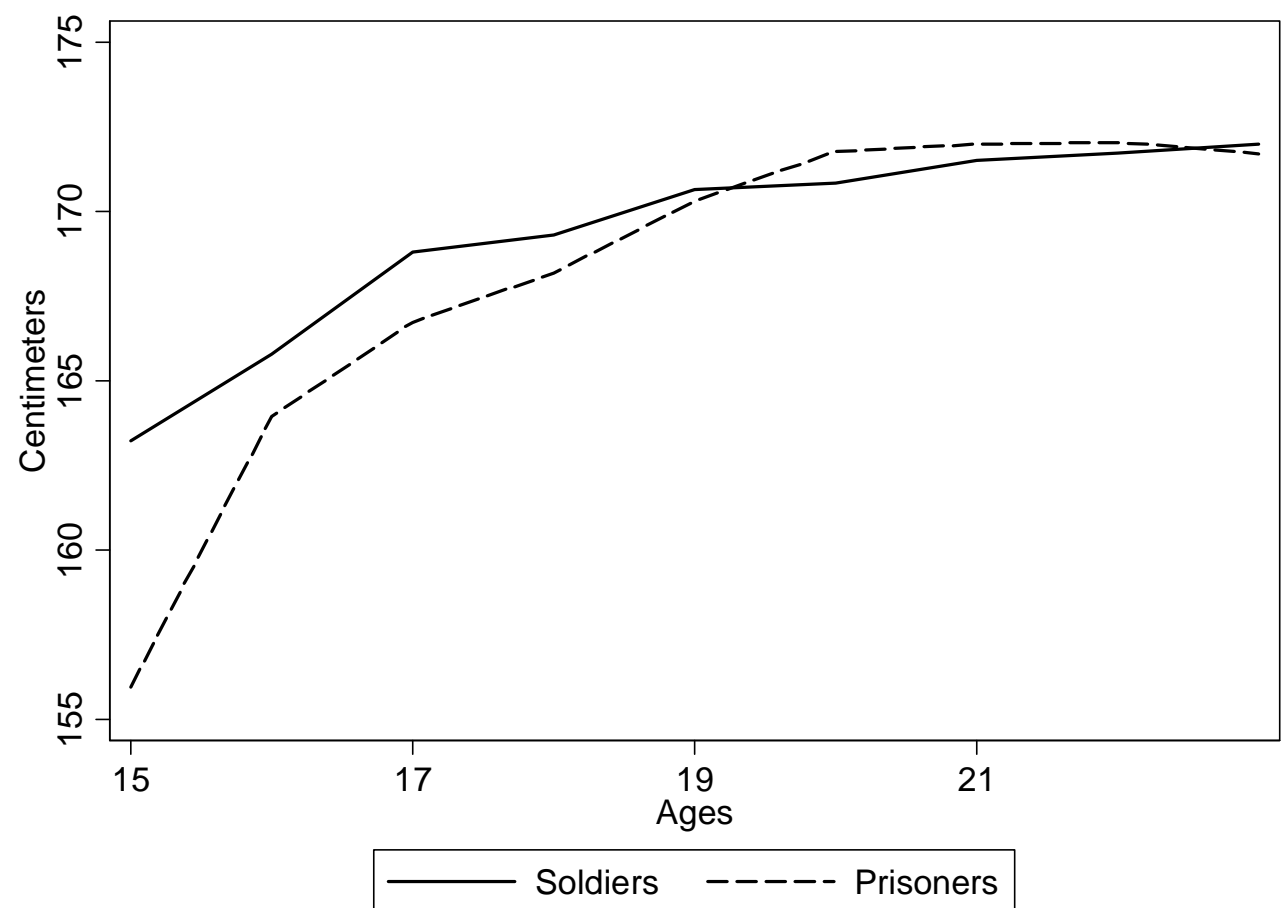

Source: See Tables 4 and 5. 
Figure 3, Nineteenth Century Soldier and Prisoner Statures by Birth Decade

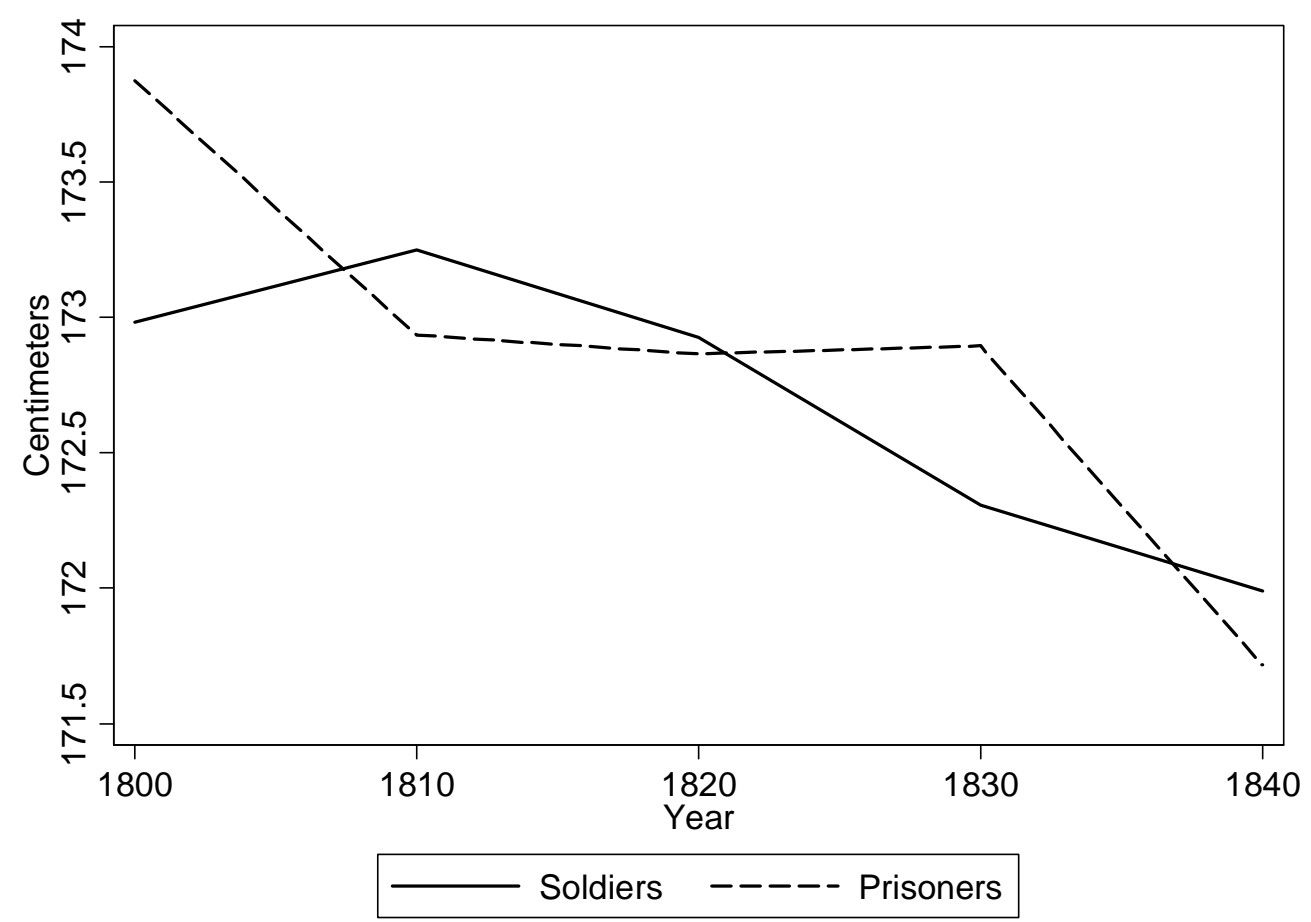

Source: See Tables 4 and 5.

Three general patterns emerge when comparing $19^{\text {th }}$ century white soldier and prisoner statures. First, stature comparisons by age and birth year demonstrate that soldiers and prisoners reached about the same terminal statures (Figures 2 and 3). The majority of soldiers were from the agricultural class, that socioeconomic group that received better nutrition allocations and lived in rural environments, where infectious disease was less easily propagated (Lee, 1997). Early $19^{\text {th }}$ century agriculture was in the early stages of commercialization, and the majority of Northeastern farmers lived on selfsufficient family farm units (Carson, 2008, p. 349). Prisoners were also taller because 
they were of Southern nativity, which was biologically beneficial because the South was rural, self-sufficient in food production, and the South also received more solar radiation. Figure 4, Nineteenth Century Soldier and Prisoner Statures by Insolation

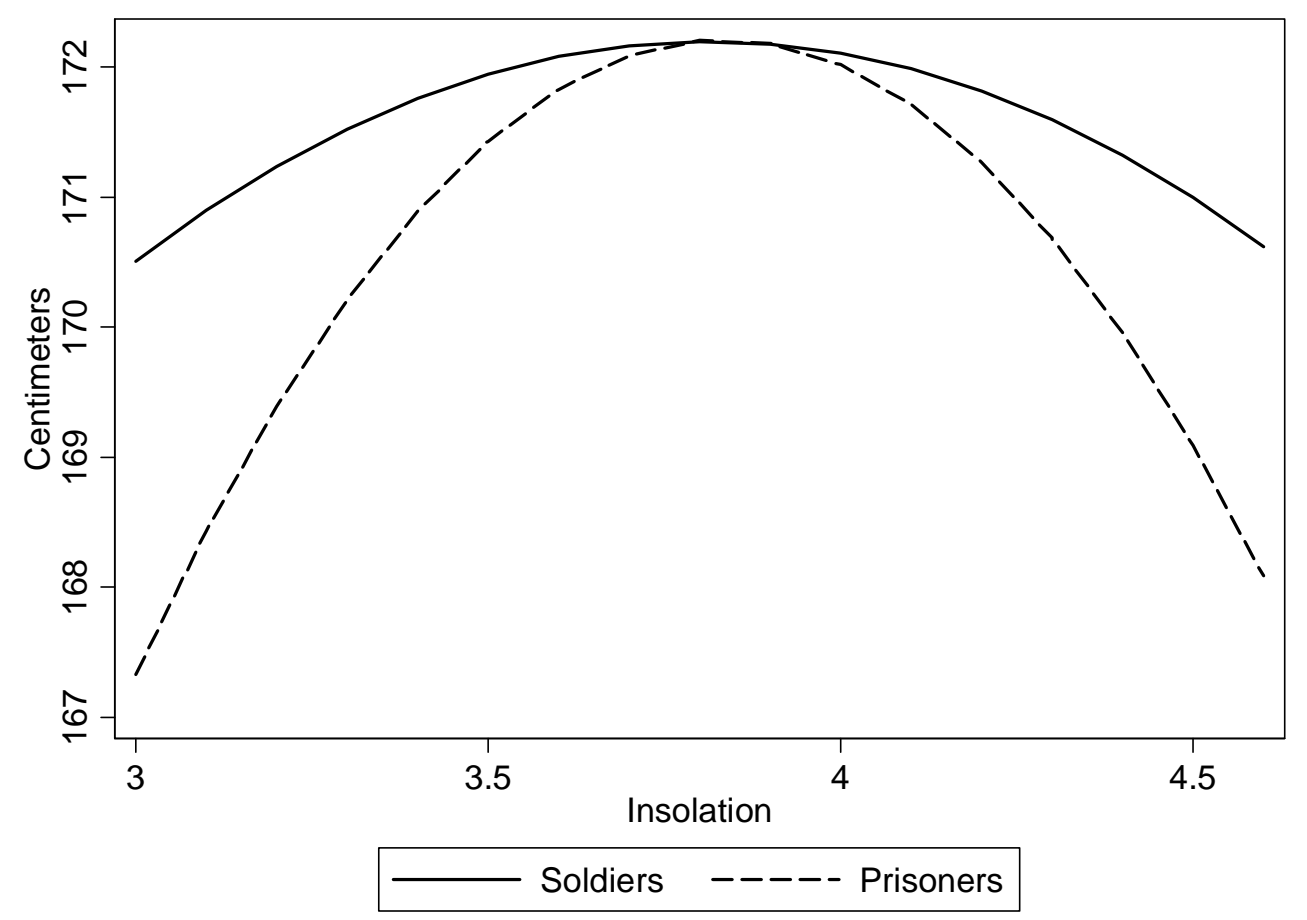

Source: See Tables 4 and 5.

Second, consistent with the insolation-stature hypothesis, insolation was positively related with soldier and prisoner statures and increased with insolation at a decreasing rate (Figure 4), and soldier and prisoner's average stature reached a maximum in insolation at 3.82 hours of incident solar radiation per day. Nonetheless, there were differences between how soldier and prisoner statures, and soldier and prisoner stature variation was sensitive to socioeconomic status. If soldier and prisoner statures are observed at average US insolation levels, soldiers and prisoners came to comparable 
terminal statures, 171.72 and $171.99 \mathrm{cms}$ respectively. If, on the other hand, soldier and prisoner statures are observed at US insolation extremes, the soldier-prisoner stature differential was large. For example, observed at the lowest state-insolation level, Maine, soldiers were shorter than prisoners, 171.04 to 171.81 centimeters, respectively. Observed at the highest state-insolation level, Arizona, prisoners were taller than soldiers, 167.15 to 158.7 centimeters, respectively. The prisoner stature advantage in insolation indicates prisoner's, who likely received smaller stature benefits from other sources and had larger stature growth with insolation. Therefore, there was an absolute maximum stature that whites reach with insolation, and insolation effects differed by socioeconomic status at the extremes. ${ }^{9}$

Sensitivity analysis indicates the omission of insolation had considerable interaction with nativity. A joint test for soldiers and prisoner statures on insolation variables illustrates that insolation's omission over estimates the effect of nativity with stature, while having little effect on other variable slope coefficients; insolation omission also upwardly biases the intercept (Soldiers, F-Statistic: 48.36, $p=.0000$; Prisoners, FStatistic: $14.68, \mathrm{p}=.0000$ ), indicating that when insolation is omitted the asymptotic bias on stature with nativity variables and the intercept are positive (Woolridge, 2002, p. 62; Woolridge, 2003. p. 92, Table 3.2).

Third, after controlling for insolation, $19^{\text {th }}$ century farmers were at a biological advantage to workers in other occupations, and the farmer stature advantage for both soldiers and prisoners was remarkably similar (Table 3, Models 1 and 4). Farmers

\footnotetext{
${ }^{9}$ Average US insolation is 4.33; average Maine insolation is 3.43; average Missouri insolation is 4.16; average Arizona is 5.22.
} 
traditionally had greater access to superior diets and nutrition. An additional explanation to nutrition and disease is that farmers worked outdoors and were exposed to greater sunlight during adolescent ages. Islam et al. (2007, pp. 383-388) demonstrates that children were exposed to more sunlight and produced more vitamin D, and if there was little movement away from parental occupations, $19^{\text {th }}$ century occupations may also be a good indicator for the occupational environment in which individuals came to maturity (Costa, 1993, p. 367; Margo and Steckel, 1992, p. 520; Burdieu, Ferrie, and Kesztenbaum, 2009).

Occupation omission effects on restricted model coefficients are similar between soldiers and prisoners. A joint test on socioeconomic status has little effect on other restricted model slope coefficients; however, socioeconomic status was jointly related with stature (F-statistic: Soldiers, 104.52, $\mathrm{p}=.0000$; Prisoners, 62.75, $\mathrm{p}=.0000$ ). Socioeconomic status omission did not influence the stature relationship with other variables. Consequently, stature and socioeconomic status may also be related to inslotion and vitamin D production but not other variables (Badiwala et al., 2003, pp. 659-660; Holick, et al., 1981, p. 590).

Other patterns are consistent with expectations. Both soldier and prisoner statures declined throughout the first half the $19^{\text {th }}$ century (Figure 3). Between 1800 and 1840 , white soldier and prisoner statures declined by about two cms. These stature declines are comparable to those observed for National Guardsman reported by Steckel and Haurin (1994) and prisoners reported by Carson (2008 and 2009). Moreover, birth period omission effects are similar between soldiers and prisoners. A joint test on birth-period effects has little influence on other restricted model slope coefficients; however, birth- 
period was related with stature variation (F-statistic: Soldiers: $13.68, \mathrm{p}=.0000$; Prisoners: 32.07, $\mathrm{p}=.0000$ ), indicating that birth-period was significantly related with stature, and the omission of birth-period variables does not influence other variable interactions with stature.

White statures varied regionally, and Southern whites were taller than Northern whites. Part of the Southern stature advantage was also related to Southern agriculture. The $19^{\text {th }}$ century opening of the New South to agriculture increased Southwestern agricultural productivity, which was higher than elsewhere within the US (Margo and Steckel, 1983, pp. 169-170; Steckel and Haurin, 1994, pp. 125-127). Nativity omission effects on restricted model coefficients are similar between soldiers and prisoners. A joint test on nativity for both soldiers and prisoners downwardly biases the relationship between being a insolation and stature (F-Statistic, Soldiers: 8.73, $p=.0000$; Prisoners: FStatistic, 69.01, $\mathrm{p}=.0000)$.

\section{Conclusion}

This paper uses two large independently collected samples of European-American soldiers and prisoners to test how white statures varied by insolation for two different socioeconomic groups. Three observations are observed and are consistent with the existing literature. First, white Civil War recruits and prisoners came to about the same statures; however, this result must be interpreted with caution. While soldiers came from the agricultural class, prisoners were from the South and benefited from greater agricultural productivity; the South also receives more insolation. Second, soldier and prisoner statures were related with insolation in remarkably similar ways. White soldier and prisoner statures increased with insolation at a decreasing rate, and the threshold 
where stature reaches its maximum in insolation is similar. Third, although the soldier sample is clearly drawn from higher socioeconomic status, the farmer stature advantage for military and prison samples was similar. The effects of insolation omission are also coming into focus. Nativity was related to stature, and this paper demonstrates that studies that do not account for nativity may underestimate the relationship between stature and nativity. The effect of omitting socioeconomic status and birth period variables however has little relationship between stature and other variables. 


\section{References}

Bodenhorn, Howard. “A Troublesome Caste: Height and Nutrition of Antebellum Virginia’s Rural Free Blacks.” Journal of Economic History 59, 4 (1999): 972996.

Bodiwala, Dhaval, Christopher Luscombe, Samson Liu, Mark Saxby, Michael French, Peter Jones, Anthony Fryer and Richard Strange. 2003, “Prostate Cancer Risk and Exposure to Ultraviolet Radiation: Further Support of the Protective Effect of Sunlight,” Cancer Letters v. 192, pp. 145-146.

Bogin, B. (1991). Measurement of Growth Variability and Environmental Quality in Guatemalan Children. Annals of Human Biology 18, 285-294.

Carson, S. (2008). The Effects of Geography and Vitamin D on African American Stature in the $19^{\text {th }}$ Century: Evidence from Prison Records, Journal of Economic History, 68, 812-831.

Carson, S. (2009). Geography, Insolation, and Vitamin D in $19^{\text {th }}$ Century US AfricanAmerican and White Statures. Explorations in Economic History 46, 149-159.

Case, Ann and Christina Paxson. "Height, Health, and Cognitive Function at Older Ages,” American Economic Review 98, 3 (2008): 463-467.

Costa, Dora, 1993, “Height, Wealth and Disease among the Native-Born in the Rural Antebellum North,” Social Science History Association, 17(3), pp. 355-383. Deaton, Angus. "Height, Health, and Inequality: The Distribution of Adult Heights in India.” American Economic Review 98, 2 (2008): 468-474.

Fogel, Robert W. “Economic Growth, Population Theory and Physiology: The Bearing of Long-Term Processes on the Making of Economic Policy,” American Economic 
Review 84(3), 1994, pp. 369-395.

Garland, Cedric F, Frank Garland, Edward Gorhom, Margin Lipkin, Harold Newmark, Sharif Mohr, and Michael Holick. (2006) "The Role of Vitamin D in Cancer Prevention.” American Journal of Public Health. 96(2). pp. 252-261.

Ginsburg, E, G. Livshits, K. Yakovenko and E. Kobyliansky, “Major Gene Control of Human Body Height, Weight and BMI in Five Ethnically Different Populations.” Annals of Human Genetics 62, (1998): 307-322.

Grant, William (2003) “Ecological Studies of Solar UV-B Radiation and Cancer Mortality Rates,” Resent Results in Cancer Research. 164, pp. 371-377. Holick, Michael F., A. MacLaughlin, and S. H. Doppelt (1981) "Regulation of Cutaneous Previtamin $\mathrm{D}_{3}$ Photosynthesis in Men: Skin Pigment is not an Essential Regulator.” Science, 211(6), pp. 590-593.

Holick, Michael F., (2001) “A Perspective on the Beneficial Effects of Moderate Exposure to Sunlight: Bone Health, Cancer Prevention, Mental Health and Well Being,” Ed. Giacomoni, Paolo, Sun Protection in Man. Elsevier: Amersterdam. Holick, Michael F, “Vitamin D: Importance in the Prevention of Cancers, Type 1 Diabetes, Heart Disease and Osteroporosis.” American Journal of Clinical Nutrition 79. 2004a. pp. 362-371.

Holick, Michael, 2004b, “Sunlight and Vitamin D for Bone Health and Prevention of Autoimmune Diseases, Cancers, and Cardiovascular Diseases,” American Journal of Clinical Nutrition, supplement, pp. 1678S-1688S.

Holick, Michael F, 2007 “Vitamin D Deficiency.” New England Journal of Medicine 357(3). pp. 266-281. 
Islam, Talat, W. James Gauderman, Wendy Cozen, Thomas Mack, 2007, “Childhood Sun Exposure Influences Rick of Multiple Sclerosis in Monozygotic Twins,” Neurology 69, pp. 381-388.

Jablonski, Nina (2006) Skin: A Natural History. Berkeley: University of California Press. Komlos, John. “The Height and Weight of West Point Cadets: Dietary Change in Antebellum America.” Journal of Economic History 47, no. 4 (December 1987): 897-927.

Komlos, John. “Toward an Anthropometric History of African-Americans: The Case of the Free Blacks in Antebellum Maryland.” in Strategic Factors in Nineteenth Century American Economic History: A Volume to Honor Robert W. Fogel, edited by Claudia Goldin and Hugh Rockoff. Chicago: University of Chicago Press. 1992, 297-329.

Komlos, John and Peter Coclanis. “On the Puzzling Cycle in the Biological Standard of Living: The Case of Antebellum Georgia.” Explorations in Economic History. 34, no. 4 (October, 1997): 433-59.

Komlos, John and Jörg Baten (2004) “Anthropometric Research and the Development of Social Science History. Social Science History. 28: 191-210.

Le Roy Ladurie, E., 1979, The Conscripts of 1968: A Study of the Correlation between Geographical Mobility, Delinquency and Physical Stature and Other Aspects of the Situation of the Young Frenchman Called to Do Military Service that Year. In: Reynolds B, Reynolds S, editors. The Territory of the Historian, (Chicago: University of Chicago Press). 33-60.

Loomis, W. Farnsworth, 1967, “Skin-Pigment Regulation of Vitamin-D Biosynthesis in 
Man: Variation in Solar Ultraviolet at Different Latitudes may have Caused Racial Differentiation in May,” Science, pp. 501-506.

Margo, Robert, and Richard H. Steckel (1983) “Heights of Native Born Northern Whites during the Antebellum Era.” Journal of Economic History 43: 167-174.

Margo, Robert and Richard Steckel. 1992, “The Nutrition and Health of Slaves and antebellum Southern whites." in Without Consent or Contract: Conditions of Slave Life and the Transition to Freedom, edited by R. W. Fogel and S. L. Engerman, New York: Norton, 508-521.

McPherson, James., Battle Cry of Freedom. Oxford University Press: Oxford. (1988).

Nesby-O’Dell, Shanna, Kelley Scanlon, Mary Cogswell, Cathleen Gillesie, Bruce Hollis Anne Looker, Chris Allen, Cindy Doughertly, Elaine Gunter, and Barbara Bowman. "Hypovitaminosis D Prevalence and Determinants among AfricanAmerican and White Woman of Reproductive Age: Third National Health and Nutrition Examination Survey, 1988-1994.” American Journal Clinical Nutrition 76. 2002. pp. 187-192.

Nicholas, Stephen and Richard Steckel, "Heights and Living Standards of English Workers During the Early Years of Industrialization.” Journal of Economic History. 51(4), 1991, pp. 937-957.

Norman, Anthony, “Sunlight, Season, Skin Pigmentation, Vitamin D and 25hydroxyvatamin D: Integral Components of the Vitamin D Endocrine System,” American Journal of Clinical Nutrition, 67. 1998, pp. 1108-1110.

Rosenbloom, Joshua, Looking for Work, Searching for Workers: American Labor 
Markets during Industrialization. Cambridge: Cambridge University Press, 2002. Steckel, Richard, 1979, “Slave Height Profiles from Coastwise Manifests,” Explorations in Economic History 16, pp. 363-380.

Steckel, R. (1992) Work Disease and Diet in the Health and Mortality of American Slaves. In: Fogel, R. W., (ed.) Without Consent or Contract: Conditions of Slave Life and the Transition to Freedom. Norton, New York, 489-507.

Steckel, Richard H. (1995) “Stature and the Standard of Living.” Journal of Economic Literature 33, 1903-1940.

Steckel, R.H. \& Haurin, D. (1994) "Health and Nutrition in the American Midwest: Evidence from the Height of Ohio National Guardsman 1850-1910.” In: Komlos, J. (Ed.), Stature, Living Standards and Economic Development. University Press of Chicago, Chicago, 117-128.

Sunder, Marco (2004) “The Height of Tennessee Convicts: Another Pieces of the “Antebellum Puzzle”. Economics and Human Biology. pp. 75-86.

Tanner, James M. Growth at Adolescence. Springfield, IL: Charles C. Thomas. 1962. Tanner, James M, 1977, “Human Growth and Constitution,” in Harrison, GA, Weiner, JS, Tanner, JM, and Barnicot, NA (eds) Human Biology: an Introduction to Human Evolution, Variation, Growth and Ecology. pp. 301-384.

Tortolani, Justin, Edward McCarthy, Paul Sponseller, 2002, “Bone Mineral Density Deficiency in Children,” Journal of the American Academy of Orthopedic Surgeons, 10(1) pp. 57-66.

Utterlinden, André, Yue Fang, Joyce B.J. van Meurs, Huibert A. P. Pols, Johannes P.T.M 
van Leeuwen, “Genetic and Biology of Vitamin D Receptor Polymorphisms,” Gene, 338, (2004): 143-156.

Wardlaw, G.M., J.S. Hampl, and R.A. Disilestro, 2004, Perspectives in Nutrition, $6^{\text {th }}$ ed., New York: McGraw-Hill, pp. 394-397.

Woolridge, Jeffrey, 2002, Economic Analysis of Cross Section and Panel Data. MIT Press: Cambridge, MA.

Woolridge, Jeffrey, 2003, Introductory Econometrics: a Modern Approach, $2^{\text {nd }}$ ed. Thomson South-Western, USA.

Xiong, E-H, F-H Xu, P-Y Liu, H Shen, J-R Long, L Elze, R R Recker and H-W Deng, “Vitamin D Receptor Gene Polymorphisms are Linked to and Associated with Adult Height,” Journal of Medical Genetics, 42, (2004): 228-234.

Y-Z Liu, F-H Shen, H Deng, Y-J Liu, L-J Zhao, V Dvornyk, T Conway, J-L Li, Q-Y Huang, K M Davies, R R Recker, and H-W Deng, “Confirmation Linkage Study in Support of the X Chromosome Harboring a ATL Underlying Human Height Variation,” Journal of Medical Genetics, 40, (2003): 825-831. 


\section{CESifo Working Paper Series}

for full list see www.cesifo-group.org/wp

(address: Poschingerstr. 5, 81679 Munich, Germany, office@cesifo.de)

2789 Sebastian G. Kessing, Federalism and Accountability with Distorted Election Choices, September 2009

2790 Daniel Gros, Global Welfare Implications of Carbon Border Taxes, September 2009

2791 Louis N. Christofides, Michael Hoy and Ling Yang, The Gender Imbalance in Participation in Canadian Universities (1977-2005), September 2009

2792 Jan K. Brueckner and Robert W. Helsley, Sprawl and Blight, September 2009

2793 Vidar Christiansen and Stephen Smith, Externality-correcting Taxes and Regulation, September 2009

2794 John Beirne, Guglielmo Maria Caporale, Marianne Schulze-Ghattas and Nicola Spagnolo, Global and Regional Spillovers in Emerging Stock Markets: A Multivariate GARCH-in-mean Analysis, September 2009

2795 Rüdiger Pethig and Frieder Kolleß, Asymmetric Capital-Tax Competition, Unemployment and Losses from Capital Market Integration, September 2009

2796 Ngo Van Long, Horst Raff and Frank Stähler, Innovation and Trade with Heterogeneous Firms, September 2009

2797 Margit Osterloh and Bruno S. Frey, Research Governance in Academia: Are there Alternatives to Academic Rankings?, September 2009

2798 Thiess Buettner and Clemens Fuest, The Role of the Corporate Income Tax as an Automatic Stabilizer, September 2009

2799 Annette Alstadsæter, Measuring the Consumption Value of Higher Education, September 2009

2800 Peter Friedrich, Chang Woon Nam and Janno Reiljan, Local Fiscal Equalization in Estonia: Is a Reform Necessary?, September 2009

2801 Evžen Kočenda and Jan Hanousek, State Ownership and Control in the Czech Republic, September 2009

2802 Michael Stimmelmayr, Wage Inequality in Germany: Disentangling Demand and Supply Effects, September 2009

2803 Biswa N. Bhattacharyay, Towards a Macroprudential Surveillance and Remedial Policy Formulation System for Monitoring Financial Crisis, September 2009 
2804 Margarita Katsimi, Sarantis Kalyvitis and Thomas Moutos, "Unwarranted" Wage Changes and the Return on Capital, September 2009

2805 Christian Lessmann and Gunther Markwardt, Aid, Growth and Devolution, September 2009

2806 Bas Jacobs and Dirk Schindler, On the Desirability of Taxing Capital Income to Reduce Moral Hazard in Social Insurance, September 2009

2807 Hans Gersbach and Noemi Hummel, Climate Policy and Development, September 2009

2808 David E. Wildasin, Fiscal Competition for Imperfectly-Mobile Labor and Capital: A Comparative Dynamic Analysis, September 2009

2809 Johan Eyckmans and Cathrine Hagem, The European Union's Potential for Strategic Emissions Trading through Minimal Permit Sale Contracts, September 2009

2810 Ruediger Bachmann and Christian Bayer, The Cross-section of Firms over the Business Cycle: New Facts and a DSGE Exploration, October 2009

2811 Slobodan Djajić and Michael S. Michael, Temporary Migration Policies and Welfare of the Host and Source Countries: A Game-Theoretic Approach, October 2009

2812 Devis Geron, Social Security Incidence under Uncertainty Assessing Italian Reforms, October 2009

2813 Max-Stephan Schulze and Nikolaus Wolf, Economic Nationalism and Economic Integration: The Austro-Hungarian Empire in the Late Nineteenth Century, October 2009

2814 Emilia Simeonova, Out of Sight, Out of Mind? The Impact of Natural Disasters on Pregnancy Outcomes, October 2009

2815 Dan Kovenock and Brian Roberson, Non-Partisan 'Get-Out-the-Vote' Efforts and Policy Outcomes, October 2009

2816 Sascha O. Becker, Erik Hornung and Ludger Woessmann, Catch Me If You Can: Education and Catch-up in the Industrial Revolution, October 2009

2817 Horst Raff and Nicolas Schmitt, Imports, Pass-Through, and the Structure of Retail Markets, October 2009

2818 Paul De Grauwe and Daniel Gros, A New Two-Pillar Strategy for the ECB, October 2009

2819 Guglielmo Maria Caporale, Thouraya Hadj Amor and Christophe Rault, International Financial Integration and Real Exchange Rate Long-Run Dynamics in Emerging Countries: Some Panel Evidence, October 2009 
2820 Saša Žiković and Randall K. Filer, Hybrid Historical Simulation VaR and ES: Performance in Developed and Emerging Markets, October 2009

2821 Panu Poutvaara and Andreas Wagener, The Political Economy of Conscription, October 2009

2822 Steinar Holden and Åsa Rosén, Discrimination and Employment Protection, October 2009

2823 David G. Mayes, Banking Crisis Resolution Policy - Lessons from Recent Experience Which elements are needed for robust and efficient crisis resolution?, October 2009

2824 Christoph A. Schaltegger, Frank Somogyi and Jan-Egbert Sturm, Tax Competition and Income Sorting: Evidence from the Zurich Metropolitan Area, October 2009

2825 Natasa Bilkic, Thomas Gries and Margarethe Pilichowski, Stay in School or Start Working? - The Human Capital Investment Decision under Uncertainty and Irreversibility, October 2009

2826 Hartmut Egger and Udo Kreickemeier, Worker-Specific Effects of Globalisation, October 2009

2827 Alexander Fink and Thomas Stratmann, Institutionalized Bailouts and Fiscal Policy: The Consequences of Soft Budget Constraints, October 2009

2828 Wolfgang Ochel and Anja Rohwer, Reduction of Employment Protection in Europe: A Comparative Fuzzy-Set Analysis, October 2009

2829 Rainald Borck and Martin Wimbersky, Political Economics of Higher Education Finance, October 2009

2830 Torfinn Harding and Frederick van der Ploeg, Is Norway's Bird-in-Hand Stabilization Fund Prudent Enough? Fiscal Reactions to Hydrocarbon Windfalls and Graying Populations, October 2009

2831 Klaus Wälde, Production Technologies in Stochastic Continuous Time Models, October 2009

2832 Biswa Bhattacharyay, Dennis Dlugosch, Benedikt Kolb, Kajal Lahiri, Irshat Mukhametov and Gernot Nerb, Early Warning System for Economic and Financial Risks in Kazakhstan, October 2009

2833 Jean-Claude Trichet, The ECB's Enhanced Credit Support, October 2009

2834 Hans Gersbach, Campaigns, Political Mobility, and Communication, October 2009

2835 Ansgar Belke, Gunther Schnabl and Holger Zemanek, Real Convergence, Capital Flows, and Competitiveness in Central and Eastern Europe, October 2009 
2836 Bruno S. Frey, Simon Luechinger and Alois Stutzer, The Life Satisfaction Approach to Environmental Valuation, October 2009

2837 Christoph Böhringer and Knut Einar Rosendahl, Green Serves the Dirtiest: On the Interaction between Black and Green Quotas, October 2009

2838 Katarina Keller, Panu Poutvaara and Andreas Wagener, Does Military Draft Discourage Enrollment in Higher Education? Evidence from OECD Countries, October 2009

2839 Giovanni Cespa and Xavier Vives, Dynamic Trading and Asset Prices: Keynes vs. Hayek, October 2009

2840 Jan Boone and Jan C. van Ours, Why is there a Spike in the Job Finding Rate at Benefit Exhaustion?, October 2009

2841 Andreas Knabe, Steffen Rätzel and Stephan L. Thomsen, Right-Wing Extremism and the Well-Being of Immigrants, October 2009

2842 Andrea Weber and Christine Zulehner, Competition and Gender Prejudice: Are Discriminatory Employers Doomed to Fail?, November 2009

2843 Hadi Salehi Esfahani, Kamiar Mohaddes and M. Hashem Pesaran, Oil Exports and the Iranian Economy, November 2009

2844 Ruediger Bachmann and Christian Bayer, Firm-Specific Productivity Risk over the Business Cycle: Facts and Aggregate Implications, November 2009

2845 Guglielmo Maria Caporale, Burcu Erdogan and Vladimir Kuzin, Testing for Convergence in Stock Markets: A Non-Linear Factor Approach, November 2009

2846 Michèle Belot and Jan Fidrmuc, Anthropometry of Love - Height and Gender Asymmetries in Interethnic Marriages, November 2009

2847 Volker Nitsch and Nikolaus Wolf, Tear Down this Wall: On the Persistence of Borders in Trade, November 2009

2848 Jan K. Brueckner and Stef Proost, Carve-Outs Under Airline Antitrust Immunity, November 2009

2849 Margarita Katsimi and Vassilis Sarantides, The Impact of Fiscal Policy on Profits, November 2009

2850 Scott Alan Carson, The Relationship between Stature and Insolation: Evidence from Soldiers and Prisoners, November 2009 